of the Atlantic Rainforest in recent decades, which is crucial to understanding the recent trends in environmental degradation in São Paulo state. An attempt to reconstruct the forest cover of the state was done by Victor (1975) and Victor et al. (2005) based on reports of pioneers and naturalists, the rise and mobility of population, agriculture expansion and more recently on aerial photo interpretation. It shows that the forest cover of the state was drastically reduced (Fig. 2) by the spread of agriculture and industrialization. The amount of forest cover remaining today corresponds to 2, 8 and $55 \%$ of the original area in Campinas, Bauru and $\mathrm{Cu}$ batão, respectively.

\section{Future Directions}

From the perspectives of both local sustainable development and global change, São Paulo is a "hot spot". There is a great need to break the cycle of destruction and reconstruction linked to catastrophic events. Knowledge of the extent of histori- cal environmental degradation through depletion of resources, such as has occurred in the Atlantic Forest, and a comprehensive evaluation of the frequency and magnitude of floods and landslides are essential to understanding the evolution of natural disasters. Further studies that take into account the characteristics of the river channel network, the sediment yield from these catchments, the landslide scars, and the weathering and soil development must encompass at least decadal timescales in order to provide rates and nature of changes that take place over planning timescales. The evaluation of current economic development strategies, including policies, guidelines and laws, are vitally important to develop strategies that can lead the entire region towards a more sustainable development trajectory. Planning must be constrained by rules that are defined and rooted in long-term and regional to inter-regional analyses of the optimum and sustainable uses of space.

\section{Acknowledgements}

I thank Daniel Henrique Candido, PhD student at UNICAMP for the improvement of the figures, and MsD. Ciro Koiti Matsukuma and Valdir de Cicco, Instituto Florestal, for providing the information on deforestation. I also thank Dr. Francisco Sergio Bernardes Ladeira, UNICAMP and Professor John Dearing, University of Southampton, for valuable suggestions.

\section{References}

Almeida Filho, G.S. and Coiado, E.M., 2001: Processos erosivos lineares associados a eventos pluviosos na área urbana do município de Bauru, SP. Avaliable at: http://www.labogef.iesa.ufg.br/links/ simposio_erosao/articles/T085.pdf

Araki, R. and Nunes, L.H., 2008: Vulnerability associated with precipitation and anthropogenic factors in Guarujá City (São Paulo, Brazil) from 1965 to 2001, Terrae - Geoscience, Geography, Environment, 3(1): 40-45

Castellano, M.S., 2010: Inundações em Campinas (SP) entre 1958 e 2007 : tendências socioespaciais e as ações do poder público, Master Dissertation, IG-UNICAMP, (English Abstract).

Changnon, S.A., Pielke Jr, R.A., Changnon, D., Sylves, R.T. and Pulwarty, R., 2000: Human factors explain the increased losses from weather and climate extremes, Bulletin of the American Meteorological Society, 81: 437-442.

Victor, M.A. de M., Cavalli, A.C., Guillaumon, J.R. and Serra Filho, R. 2005: Cem anos de devastação: revisitada 30 anos depois, Available at http://antoniocavalli.com/cem\%20anos\%20de\%20 devasta\%C3\%A7\%C3\%A30.pdf (English translation).

For full references please consult:

http://www.pages-igbp.org/products/newsletters/ref2011_2.pdf

\title{
Regional wetland response typology: Murray-Darling Basin, Australia
}

\author{
Michael Reid ${ }^{1}$ and Peter Gell ${ }^{2}$ \\ 'University of New England, Australia; mreid24@une.edu.au \\ ${ }^{2}$ University of Ballarat, Australia.
}

\section{Paleoecological records from billabongs (floodplain lakes) in southern Australia can be used to develop ecosystem response models that describe how the underlying hydrology and geomorphology of these aquatic ecosystems control their resilience to anthropogenic stressors.}

\begin{abstract}
Water demands
Lowland floodplain rivers are "hotspots" of biodiversity and productivity. The ecological importance of these environments is particularly substantial in Australian semiarid and arid environments because of the moisture subsidy they provide to riverine ecosystems (Ogden et al., 2007). In Australia's dry climate, these environments have also become extremely important for agriculture, which in turn has led to deterioration in ecosystem function and reduced biodiversity. Competing demands for water by ecological and economic systems has led to an apparently intractable debate over how best to allocate water to support sustainable agriculture and ecosystems. The recent debate over the water allocation prescriptions within the Murray Darling Basin Plan (MDBA, 2010) reveal that the changing condition of floodplain wetlands (billabongs) across the region is not well understood. In order to meet this
\end{abstract}

challenge it is vital that water is used efficiently for both agriculture and to support riverine ecosystems. The second half of this equation presents an immense challenge to scientists and managers because our understanding of riverine ecosystem function is limited by a lack of robust data on benchmark conditions, ecosystem variability, and the drivers and trajectories of change.

\section{Ecosystem histories and complexity}

Data and information needed to reconstruct ecosystem histories can be provided through paleoecological studies of wetlands. Furthermore, for a basin-wide appreciation, a regional integration of paleoecological studies can reveal the extent and timing of changes to provide broad insights into the ecological cost of the diversion of river flows to support irrigated agriculture.
While factors, such as invasive species and land use, can influence ecosystem structure and function (Roberts et al., 1995; Robertson and Rowling, 2000), floodplain aquatic ecosystems are principally driven by hydrology (Walker, 1985; Bunn et al., 2006). Thus, hydrological changes experienced by billabongs are likely to have a substantial influence on their ecology. However, while the hydrology of a river as a whole is primarily driven by extrinsic factors, the hydrology of individual billabongs is also strongly influenced by intrinsic factors, such as local adjustments in channel morphology, the deposition of sediments in secondary channels linking billabongs to the main channel, and the infilling of the billabongs themselves. Thus individual billabongs may reflect any number of environmental changes operating across a range of spatial and temporal scales. The distinction between local and regional drivers of change can 
therefore only be revealed by the integration of a suite of studies over a range of hydrological contexts.

Understanding links between stressors and billabong responses is complicated by the fact that billabongs are ecosystems and therefore have system properties such as non-linear and threshold responses to drivers and system resilience. Clearly, billabongs are not passive receptacles that receive sediments and biological remains that reflect linear relationships to broad-scale environmental drivers. Instead, spatial and temporal variability in depositional processes should be anticipated and simple "dose-response", linear relationships between billabong ecosystems and environmental drivers cannot be assumed. Given this variability and complexity, our capacity to understand the nature, degree, and magnitude of ecological change in lowland river systems is greatly enhanced by robust study designs that incorporate replication of sampling units and a framework for interpreting sediment records that reflects system behavior.

\section{Billabong typologies}

The utility and value of this approach was demonstrated in early paleoecological re- search on billabongs in the southern Murray-Darling Basin systems (Ogden, 2000; Reid, 2002, 2008; Reid et al., 2007). Here, large, deep billabongs underwent apparently rapid transitions in state from macrophyte to phytoplankton-dominance at the time of European settlement, while smaller and shallower billabongs maintained substantial submerged macrophyte communities (Fig. 1). The switch from macrophyte- to phytoplankton-dominance was clearly the most significant ecosystem change in those habitats for centuries, and even millennia, and was attributed to reduced photic depth as a result of abiotic turbidity caused by the influx of eroded soils in the region in the mid 1800s. This interpretation is supported by numerous geomorphological studies, which have demonstrated that this period of early settlement was one of intense sheet and gully erosion in south east Australia, driven by the clearing of native vegetation and the introduction of ungulate grazers (Prosser et al., 2001). The patterns observed in these studies highlight the critical importance of photic depth as a driver of ecosystem structure in Australian shallow lakes, a feature demonstrated elsewhere (Scheffer and Carpenter, 2003). A critical aspect of the findings in the southern Murray-

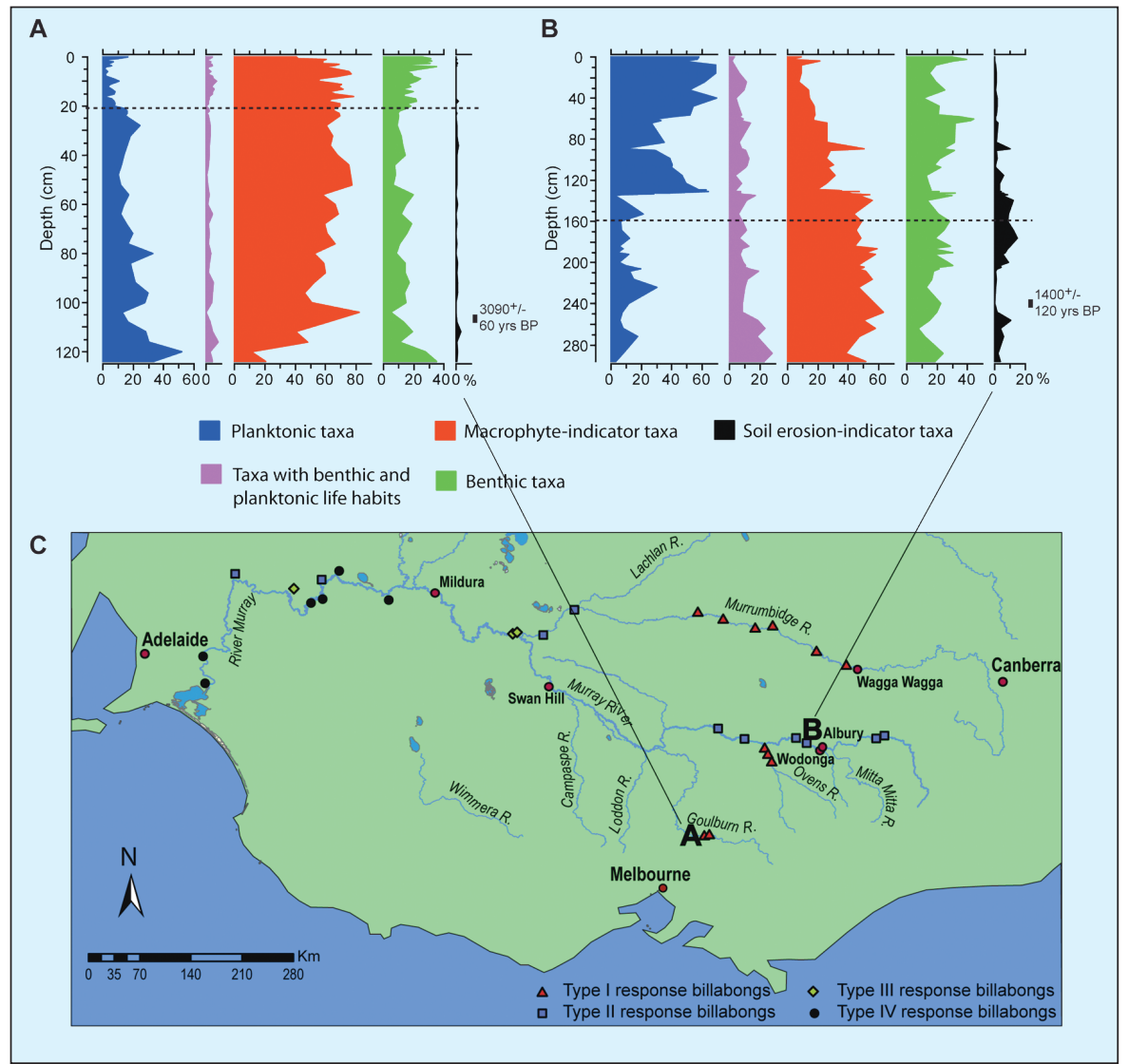

Figure 1: Examples of Type I and Type II responses in billabongs: $\boldsymbol{A})$ Persistence of macrophyte indicator diatoms (red curve) in a Type I billabong (Callemondah 1 Billabong on the Goulburn River; Reid, 2002) after settlement reflects retention of macrophyte cover, B) Diatom shifts to planktonic dominance (blue curve) in a Type ll billabong (Hogan's Billabong on the Murray River; Reid et al., 2007) after European settlement. Dotted lines indicate onset of post-European settlement sediment deposition in each billabong based on appearance of exotic pollen and physical sediment character, C) Locations of billabongs subject to paleoecological study in the Murray Darling southern basin. Symbols indicate the response type inferred from the paleorecords.
Darling Basin was the importance of the underlying morphometry in controlling the system's resilience to reduced photic depth.

This simple two-response type framework does not appear to apply to billabongs further downstream in the Murray-Darling System. Numerous studies of billabongs and floodplain wetlands on the Murray below the confluence with the Goulburn River have been carried out, and the majority of the records derived from these studies do not conform to one of the types described above (Gell et al., 2005, 2007; Fluin et al., 2010).

Although there is site-to-site variation, analysis of the full suite of records suggests four broad response types exist (Fig. 2):

- Type I: where macrophyte-dominance persists throughout the record.

- Type II: where a switch from macrophyte to phytoplankton-dominance occurs, associated with European settlement.

- Type III: where periods of phytoplankton dominance occur before and after European settlement.

- Type IV: where there appears to be few periods of "stable" macrophyte or phytoplankton-dominance.

The nature of the changes varies across the southern basin and has a broad geographical pattern:

- Billabongs from Murray tributaries (Ovens, Goulburn and Murrumbidgee) tend to exhibit a Type I response.

Billabongs from the middle Murray (between Hume Dam and the Murrumbidgee confluence) tend to exhibit a Type II response.

Billabongs from between the Murrumbidgee and the Darling tend to exhibit a Type III response.

Billabongs below the Darling tend to exhibit a Type IV response.

As the locations of sites in Figure 1 show, this pattern is not entirely consistent, particularly in the lower Murray. Nevertheless, the smaller channels of the Murray tributaries create smaller billabongs and hence a propensity for Type I responses. In contrast, the larger billabongs of the Murray are more susceptible to state changes in line with the model proposed by Ogden (2000). Further downstream, the drier climate and more variable hydrology introduces the potential for more frequent and extreme drying events. Thus, for billabongs exhibiting a Type III response, drying events may act to reset a new stable state once re-filling occurs. For billabongs exhibiting a Type IV response, drying phases may be too frequent for the establishment of strictly aquatic communities 
Type I

ED

Anthropogenic pulse in sediment input

क्ष.

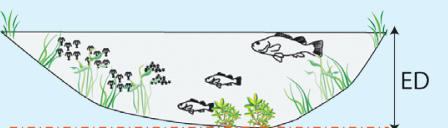

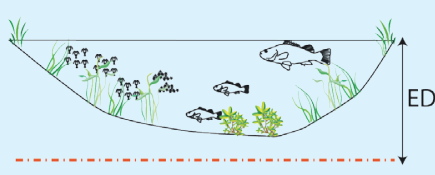

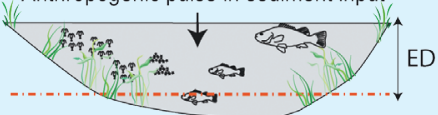

|Type II

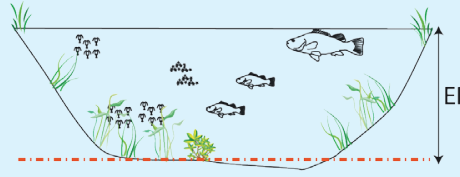

Anthropogenic pulse in sediment input

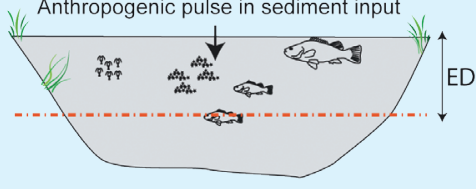

Type III

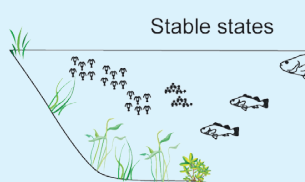

a range of locations and management scales.

\section{Implications}

This regional synthesis allows for an assessment of the sensitivity of wetlands to catchment impacts and the status of groups of wetlands relative to their historical range of condition. For wetland managers, deep, large (Type II) wetlands are at risk yet smaller (Type I) wetlands reveal some resilience to catchment impacts. Lower down the system, armed with this evidence managers may better justify reinstating wetting-drying regimes to reset turbid wetlands provided sources of sediment are controlled. Lastly, for Type IV wetlands, this research shows that a "dry wetland" is an ecologically acceptable condition and regular artificial filling may not be justified. In all instances, this evidence reinforces notions that connectivity is key, but also that sediment flux remains a strong driver of wetland condition.

\section{Data}

Metadata on the data presented in this article is available in the OZPACS database (http://www. aqua.org.au/Archive/OZPACS/OZPACS.html). The raw data are available on request from the author.

\section{References}

Figure 2: Conceptual models explaining the relationships between billabong geomorphology and hydrology and the proposed response types. In all types, dotted horizontal lines indicate the depth to which macrophytes could grow, ED = Euphotic Depth. Type I billabongs are resilient to reduced photic depth because pulses in anthropogenic sediment input do not result in reductions in photic depth sufficient to remove the majority of the billabong bed from the photic zone. Type Il billabongs are less resilient to reduced photic depth because pulses in anthropogenic sediment input result in the removal of the majority of the billabong bed from the photic zone. In both cases, feedback processes act to strengthen the original (Type I) or new (Type II) state once sediment influx is reduced. Type III billabongs behave as Type II billabongs, but can be reset to either of the stable states by drying events. Type IV billabongs undergo frequent drying events and thus develop no stable states. (planktonic or benthic) and hence these systems are dominated by opportunist taxa, such as amphibious or water tolerant terrestrial plants and algae, adapted to both benthic and pelagic habitats.

The broad geographical pattern suggests that the response types reflect the underlying geomorphology and hydrol- ogy of billabongs, because these features reflect the geomorphological and hydrological character of the parent river and reach. This understanding arises through the integration of a suite of site studies that enable the differentiation of sitespecific change and regional drivers, and so provide evidence for management at
Fluin, J., Tibby, J. and Gell, P., 2010: The palaeolimnological record from lake Cullulleraine, lower Murray River (south-east Australia): implications for understanding riverine histories, Journal of $\mathrm{Pa}$ leolimnology, 43(2): 309-322.

Gell, P., Tibby, J., Little, F., Baldwin, D. and Hancock, G., 2007: The impact of regulation and salinisation on floodplain lakes: the lower River Murray, Australia, Hydrobiologia, 591: 135-146.

Ogden, R.W., 2000: Modern and historical variation in aquatic macrophyte cover of billabongs associated with catchment development, Regulated Rivers: Research and Management, 16: 497512.

Reid, M.A., 2008: Evidence for catastrophic shifts in the trophic structure of floodplain lakes associated with soil erosion. In: Schmidt, J., et al. (Eds), Sediment Dynamics in Changing Environments, IAHS Press, 584-590.

Reid, M.A., Sayer, C.D., Kershaw, A.P. and Heijnis, H., 2007: Palaeolimnological evidence for submerged plant loss in a floodplain lake associated with accelerated catchment soil erosion (Murray River, Australia), Journal of Paleolimnology, 38: 191-208.

For full references please consult:

http://www.pages-igbp.org/products/newsletters/ref2011_2.pdf 